\title{
The relationship between the incidence of Myopia with the use of gadgets in students of Bersama Private Middle School Berastagi
}

\author{
Rodiah Rahmawaty Lubis ${ }^{1 *}$, T. Siti Harilza Zubaidah ${ }^{1}$ \\ ${ }^{1}$ Departemen Ilmu Kesehatan Mata, Fakultas Kedokteran, Universitas Sumatera Utara \\ *Email: rahma.lubis@yahoo.com
}

\begin{abstract}
Refractive errors are the failure of the eye to focus light from an object to the retina to form a clear picture. Refractive disorders are divided into myopia, hypermetropia, and astigmatism. Inadequate light, reading books, watching television and using mobile phones for long periods of time are found to be statistically significant risk factors for refractive abnormalities. The purpose of this study is to analyze the correlation between risk factors for refractive abnormalities. This research is an analytic study with cross sectional research design. Research data is primary data obtained through interviews using a research instrument in the form of a questionnaire. The results were obtained from 96 students, there were 33 students with refractive abnormalities with fewer males than females (24\% compared to $76 \%$ ). The results of statistical calculations with the Chi Square correlation test showed no significant correlation between the occurrence of refractive errors with a history of refractive errors in siblings $(\mathrm{p}=0.223)$, and there was a significant correlation between reading activity $(\mathrm{p}=0.001)$, activity using gadgets $(p=0,0001)$ and outdoor activities $(p=0.041)$. The conclusion from this study there is no meaningful correlation between the risk factors of history of refractive errors in siblings and there is a significant correlation between the risk factors of reading activity, activities using gadgets and outdoor activities on the occurrence of refractive errors in students of Bersama Private Middle School Berastagi in 2019.
\end{abstract}

Keyword: Refractive Errors, Risk Factor.

\begin{abstract}
Abstrak
Kelainan refraksi adalah kegagalan mata memfokuskan cahaya dari sebuah benda menuju retina untuk membentuk sebuah gambaran yang jelas. Kelainan refraksi terbagi atas miopia, hipermetropia, dan astigmatisma. Cahaya yang tidak memadai, membaca buku, menonton televisi dan penggunaan telefon genggam dalam durasi waktu yang lama didapati sebagai faktor risiko yang signifikan secara statistik pada kasus kelainan refraksi. Tujuan dari penelitian ini adalah menganalisis hubungan faktor risiko kelainan refraksi. Penelitian ini merupakan penelitian analitik dengan desain penelitian cross sectional. Data penelitian adalah data primer yang didapatkan melalui wawancara dengan menggunakan instrumen penelitian berupa kuesioner. Hasil penelitian didapatkan dari 96 siswa, terdapat 33 siswa dengan kelainan refraksi dengan penderita laki-laki lebih sedikit daripada perempuan (24\% dibanding 76\%). Hasil uji korelasi Chi Square memperlihatkan tidak terdapat hubungan bermakna antara terjadinya myopia dengan faktor riwayat kelainan refraksi pada saudara kandung ( $p$ $=0,223)$, dan terdapat hubungan bermakna antara aktivitas membaca $(\mathrm{p}=0,001)$, aktivitas menggunakan gadget $(\mathrm{p}=0,0001)$ dan akivitas diluar ruangan $(\mathrm{p}=0,041)$. Kesimpulan dari penelitian ini tidak terdapat hubungan yang bermaknana antara faktor risiko riwayat kelainan refraksi pada saudara kandung dan terdapat hubungan yang bermakna antara faktor risiko aktivitas membaca, aktivitas menggunakan gadget dan aktivitas diluar ruangan terhadap terjadinya kelainan refraksi pada siswa SMP Swasta Bersama Berastagi Tahun 2019.
\end{abstract}

Kata Kunci : Kelainan Refraksi, Faktor Risiko 


\section{PENDAhuluan}

Kelainan refraksi adalah kegagalan mata memfokuskan cahaya dari sebuah benda menuju retina untuk membentuk sebuah gambaran yang jelas. Kelainan ini sering menyebabkan penurunan fungsi visual. Apabila terdapat kelainan refraksi saat melihat benda yang jauh, maka mata disebutkan sebagai mata yang ametropik. Ametropia dapat dibagi menjadi miopia (rabun jauh), hipermetropia atau hiperopia (rabun dekat) dan astigmatisma (Denniston \& Murray, 2018).

Di Indonesia, sekitar 10\% dari 66 juta anak usia sekolah (5-19 tahun) mengalami kelainan refraksi dan angka pemakaian kacamata koreksi sampai saat ini masih rendah yaitu $12,5 \%$ dari kebutuhan (Adile, 2016).

Cahaya yang tidak memadai, membaca buku dalam jangka waktu yang lama, menonton televisi dan penggunaan telefon genggam dalam durasi waktu yang lama didapati sebagai faktor risiko yang signifikan secara statistik pada kasus kelainan refraksi (Kumar, et al., 2018).

Sebuah penelitan di Singapura memberikan hasil bahwa orang yang menghabiskan lebih banyak waktu di luar akan memiliki kecenderungan miopia lebih kecil. Waktu untuk bekerja dengan jarak dekat dan kurangnya aktivitas di luar ruangan merupakan faktor lingkungan yang banyak diperhatikan (Wulansari, et al., 2018).

Gangguan refraksi yang tidak diperhatikan merupakan masalah visual terkemuka di dunia pada beberapa tahun terakhir ini. Di sisi lain anak-anak merupakan generasi penerus bangsa yang harus kita kawal untuk menyongsong masa depannya. Mengingat bahwa mata merupakan panca indera yang sangat penting dan dampak yang ditimbulkan akibat gangguan pada indera ini dapat menyebabkan gangguan dalam kehidupan serta pekerjaan sehari-hari, serta menghambat perkembangan intelektualnya, maka penting sekali untuk memperhatikan masalah kesehatannya (Syafi' in \& Wibowo, 2013).

Berdasarkan latar belakang yang dijelaskan, maka peneliti tertarik untuk melakukan penelitian tentang hubungan faktor risiko terhadap terjadinya kelainan refraksi.

\section{METODE PELAKSANAAN}

Penelitian ini menggunakan jenis penelitian analitik dengan desain penelitian potong lintang (cross sectional). Penelitian ini dilakukan di SMP Swasta Bersama Berastagi. Waktu penelitian dilakukan pada bulan Juli hingga Agustus 2019 setelah mendapat ethical clearance dari komisi etik Fakultas Kedokteran Universitas Sumatera Utara-RSUP H. Adam Malik Medan.

Populasi pada penelitian ini adalah seluruh siswa yang berada di SMP Swasta Bersama Berastagi. Sampel harus memenuhi kriteria inklusi serta tidak termasuk dalam kriteria eksklusi selama penelitian berlangsung. Adapun kriteria inklusi berupa siswa SMP Swasta Bersama Berastagi yang didiagnosa dengan kelainan refraksi dan bersedia menjadi responden penelitian. Serta kriteria eksklusi yaitu responden memiliki kelainan pada kornea seperti infeksi, pasca trauma (sikatrik) dan memiliki riwayat operasi mata.

Data kemudian diolah dengan menggunakan perangkat lunak statistik dan disajikan dalam bentuk tabel. Analisa data yang dimaksud adalah analisa bivariat. Analisa bivariat digunakan untuk menyatakan analisis terhadap dua variabel, yaitu variabel dependen dan variabel independen. Pada analisa bivariat, digunakan uji Chi-Square karena seluruh variabel dependen dan independen merupakan data kategorik. Selanjutnya data akan dikumpulkan dan diolah menggunakan aplikasi statistik pada komputer.

\section{HASIL DAN PEMBAHASAN}

Data yang digunakan pada penelitian ini adalah data primer berupa wawancara dengan siswa-siswi SMP Swasta Bersama Berastagi. Penelitian dilakukan terhadap 96 siswa yang bersedia menjadi 
responden penelitian. Sampel penelitian ini adalah siswa SMP Swasta Bersama Berastagi yang telah memenuhi kriteria inklusi dan eksklusi.

Dari hasil pengumpulan data berupa wawancara serta pengukuran tajam penglihatan di SMP Swasta Bersama Berastagi, didapatkan total subjek penelitian adalah 96 responden (penderita kelainan refraksi sebanyak 33 orang dan dengan mata normal sebanyak 63 orang).

Tabel 3.1. Hubungan Karakteristik Responden dengan Terjadinya Kelainan Refraksi pada Siswa SMP Swasta Bersama Berastagi Tahun 2019.

\begin{tabular}{|c|c|c|c|c|c|c|c|c|}
\hline & & & am Peng & $\tan$ & & & & \\
\hline & Karakteristik & & & & $\begin{array}{l}\text { nan } \\
\text { ksi }\end{array}$ & & nlah & $\mathrm{p}$. \\
\hline & & $\mathrm{n}$ & $\%$ & $\mathrm{n}$ & $\%$ & $\mathrm{n}$ & $\%$ & \\
\hline Jenis & elamin & & & & & & & $0,026^{*}$ \\
\hline- & Laki-Laki & 38 & 76,0 & 12 & 24,0 & 50 & 100,0 & \\
\hline- & Perempuan & 25 & 54,3 & 21 & 45,7 & 46 & 100,0 & \\
\hline Umur & & & & & & & & 0,517 \\
\hline- & 11 Tahun & 0 & 0,0 & 1 & 100,0 & 1 & 100,0 & \\
\hline- & 12 Tahun & 7 & 87,5 & 1 & 12,5 & 8 & 100,0 & \\
\hline - & 13 Tahun & 23 & 65,7 & 12 & 34,3 & 35 & 100,0 & \\
\hline- & 14 Tahun & 23 & 65,7 & 12 & 34,3 & 35 & 100,0 & \\
\hline- & 15 Tahun & 5 & 50,0 & 5 & 50,0 & 10 & 100,0 & \\
\hline- & 16 Tahun & 4 & 66,7 & 2 & 33,3 & 6 & 100,0 & \\
\hline- & 17 Tahun & 1 & 100,0 & 0 & 0,0 & 1 & 100,0 & \\
\hline Suku & & & & & & & & 0,441 \\
\hline- & Aceh & 1 & 50,0 & 1 & 50,0 & 2 & 100,0 & \\
\hline- & Batak & 14 & 63,6 & 8 & 36,4 & 22 & 100,0 & \\
\hline- & Jawa & 4 & 50,0 & 4 & 50,0 & 8 & 100,0 & \\
\hline- & Karo & 41 & 68,3 & 19 & 31,7 & 60 & 100,0 & \\
\hline- & Melayu & 0 & 0,0 & 1 & 100,0 & 1 & 100,0 & \\
\hline- & Nias & 3 & 100,0 & 0 & 0,0 & 3 & 100,0 & \\
\hline Kelas & & & & & & & & $0,078 *$ \\
\hline- & Kelas 1 & 27 & 77,1 & 8 & 22,9 & 35 & 100,0 & \\
\hline- & Kelas 2 & 14 & 50,0 & 14 & 50,0 & 28 & 100,0 & \\
\hline & Kelas 3 & 22 & 66,7 & 11 & 33,3 & 33 & 100,0 & \\
\hline Peker & aan Orang Tua & & & & & & & $0,021 *$ \\
\hline- & Buruh & 1 & 100,0 & 0 & 0,0 & 1 & 100,0 & \\
\hline- & Pegawai & 3 & 60,0 & 2 & 40,0 & 5 & 100,0 & \\
\hline- & Agamawan & 0 & 0,0 & 1 & 100,0 & 1 & 100,0 & \\
\hline- & Petani & 43 & 78,2 & 12 & 21,8 & 55 & 100,0 & \\
\hline- & Wiraswasta & 16 & 47,1 & 18 & 52,9 & 34 & 100,0 & \\
\hline
\end{tabular}

Tabel 3.1 menunjukkan bahwa persentasi kelainan refraksi ditemukan lebih banyak pada responden wanita yaitu sebanyak 21 orang dibanding pada responden laki-laki sebanyak 12 orang. Pada umur didapatkan persentase kelainan refraksi terbanyak pada usia 13 dan 14 tahun yaitu sebanyak 12 orang. Pada suku didapatkan kelainan refraksi terbanyak pada suku Karo yaitu sebanyak 19 orang. Pada kelas didapatkan kelainan refraksi terbanyak pada siswa kelas 2 yaitu sebanyak 14 orang. Pada pekerjaan orang tua didapatkan kelainan refraksi terbanyak pada responden dengan orang tua yang berprofesi sebagai wiraswasta yaitu sebanyak 18 orang. 
Tabel 3.2. Hubungan Riwayat Keluarga Responden dengan Terjadinya Kelainan Refraksi pada Siswa SMP Swasta Bersama Berastagi Tahun 2019.

\begin{tabular}{|c|c|c|c|c|c|c|c|}
\hline \multirow{3}{*}{ Riwayat Saudara Kandung } & \multicolumn{4}{|c|}{ Tajam Penglihatan } & \multicolumn{2}{|c|}{ Jumlah } & \multirow[t]{3}{*}{ p. } \\
\hline & \multicolumn{2}{|c|}{ Normal } & \multicolumn{2}{|c|}{ Kelainan Refraksi } & \multirow[b]{2}{*}{$\mathrm{n}$} & \multirow[b]{2}{*}{$\%$} & \\
\hline & $\mathrm{n}$ & $\%$ & $\mathrm{n}$ & $\%$ & & & \\
\hline \multirow{3}{*}{$\begin{array}{c}\text { Saudara Kandung Menggunakan } \\
\text { Kacamata (Kelainan Refraksi) } \\
-\quad \text { Iya }\end{array}$} & & & & & & & 0,223 \\
\hline & & & & & & 10 & \\
\hline & 6 & 50,0 & 6 & 50,0 & 12 & $\begin{array}{c}0, \\
0\end{array}$ & \\
\hline \multirow[t]{2}{*}{ - $\quad$ Tidak } & & & & & & 10 & \\
\hline & 57 & 67,9 & 27 & 32,1 & 84 & $\begin{array}{l}0, \\
0\end{array}$ & \\
\hline \multirow[t]{2}{*}{ Jumlah } & & & & & & 10 & \\
\hline & 63 & 65,6 & 33 & 34,4 & 96 & $\begin{array}{c}0, \\
0\end{array}$ & \\
\hline
\end{tabular}

Pada riwayat saudara kandung yang menggunakan kacamata, didapati responden dengan riwayat saudara kandung menggunakan kacamata yang mengalami kelainan refraksi sebanyak 6 orang $(50,0 \%)$ dengan responden yang memiliki mata normal sebanyak 6 orang $(50,0 \%)$. Sementara pada responden dengan riwayat saudara kandung yang tidak menggunakan kacamata didapati responden yang mengalami kelainan refraksi yaitu sebanyak 27 orang $(32,1 \%)$ lebih sedikit dibandingkan dengan responden yang memiliki mata normal yaitu sebanyak 57 orang $(67,9 \%)$.

Tabel 3.3. Hubungan Aktivitas Membaca Responden dengan Terjadinya Kelainan Refraksi pada Siswa SMP Swasta Bersama Berastagi Tahun 2019.

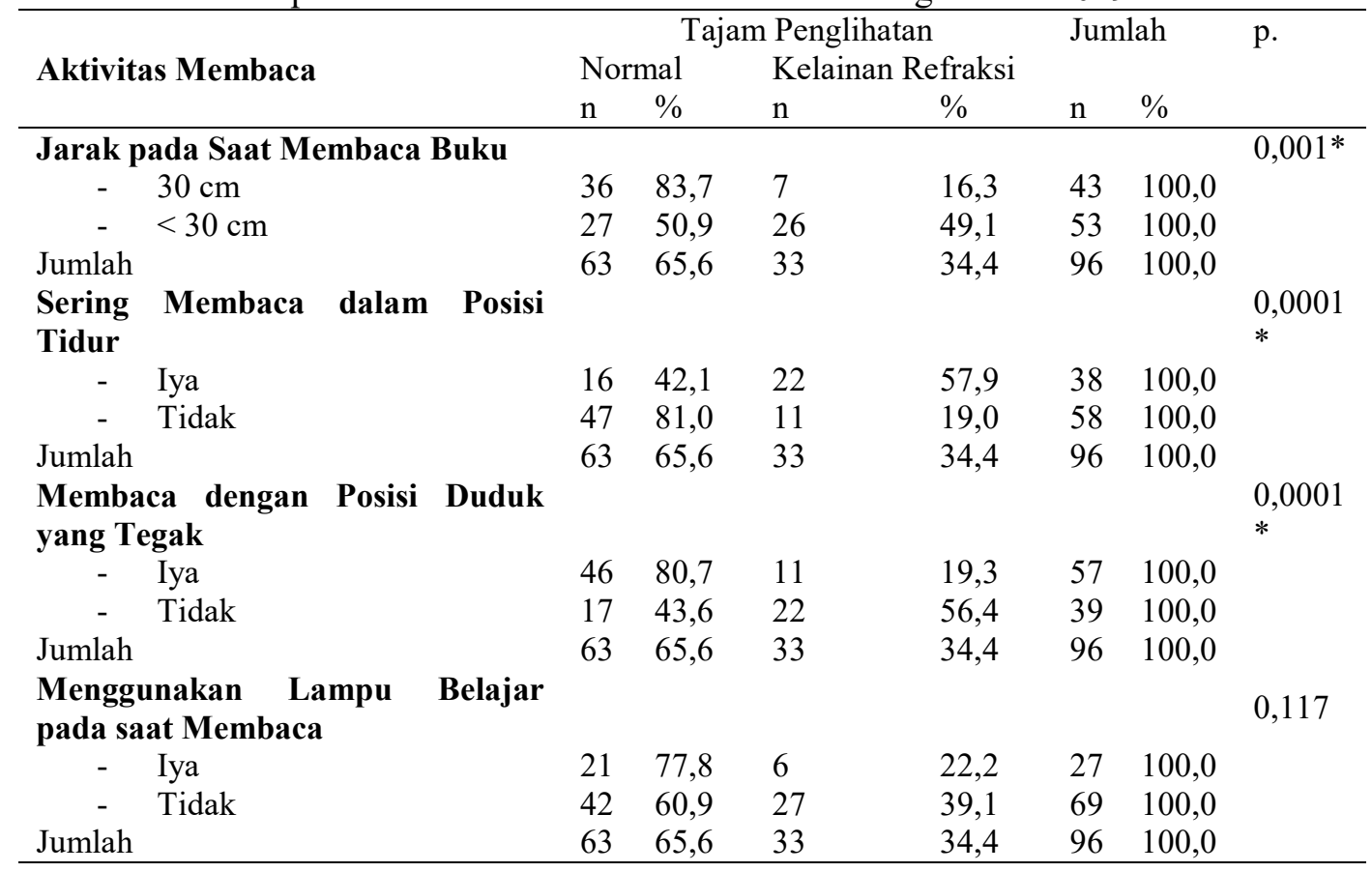

Pada tabel 3.3 dapat dilihat kelainan refraksi paling banyak terdapat pada responden yang membaca dengan jarak dibawah $30 \mathrm{~cm}$ yaitu sebanyak 26 orang. Pada sering membaca dalam posisi tidur, kelainan refraksi paling banyak ditemukan pada responden yang sering membaca dalam posisi tidur yaitu sebanyak 22 orang. Pada membaca dengan posisi duduk yang tegak, kelainan refraksi paling banyak ditemukan pada responden yang tidak membaca dengan posisi 
duduk yang tegak yaitu sebanyak 22 orang. Pada menggunakan lampu belajar pada saat membaca, kelainan refraksi paling banyak ditemukan pada responden yang tidak menggunakan lampu belajar pada saat membaca yaitu sebanyak 27 orang.

Tabel 3.4. Tabel Hubungan Aktivitas Menggunakan Gadget Responden dengan Terjadinya Kelainan Refraksi pada Siswa SMP Swasta Bersama Berastagi Tahun 2019.

\begin{tabular}{|c|c|c|c|c|c|c|c|}
\hline \multirow{3}{*}{$\begin{array}{c}\text { Aktivitas Menggunakan } \\
\text { Gadget }\end{array}$} & \multicolumn{4}{|c|}{ Tajam Penglihatan } & \multirow{2}{*}{\multicolumn{2}{|c|}{ Jumlah }} & \multirow{3}{*}{ p. } \\
\hline & \multicolumn{2}{|c|}{ Normal } & \multicolumn{2}{|c|}{ Kelainan Refraksi } & & & \\
\hline & $\mathrm{n}$ & $\%$ & $\mathrm{n}$ & $\%$ & $\mathrm{n}$ & $\%$ & \\
\hline $\begin{array}{c}\text { Lama Menggunakan Gadget } \\
\text { dalam Sekali Pemakaian }\end{array}$ & & & & & & & $0.0001 *$ \\
\hline$-<2$ jam terus menerus & 44 & 81,5 & 10 & 18,5 & 54 & 100,0 & \\
\hline \multirow{2}{*}{$\begin{array}{c}->2 \text { jam terus menerus } \\
\text { Jumlah }\end{array}$} & 19 & 45,2 & 23 & 54,8 & 42 & 100,0 & \\
\hline & 63 & 65,6 & 33 & 34,4 & 96 & 100,0 & \\
\hline \multirow{4}{*}{$\begin{array}{l}\text { Sering Menggunakan Gadget } \\
\text { dalam Posisi Tidur } \\
-\quad \text { Iya } \\
-\quad \text { Tidak }\end{array}$} & & & & & & & $0,023 *$ \\
\hline & 37 & 57,8 & 27 & 42,2 & 64 & 100,0 & \\
\hline & 26 & 81,2 & 6 & 18,8 & 32 & 100,0 & \\
\hline & 63 & 65,6 & 33 & 34,4 & 96 & 100,0 & \\
\hline
\end{tabular}

Dari tabel 3.4, pada lama menggunakan gadget dalam sekali pemakaian ditemukan kelainan refraksi paling banyak pada responden yang menggunakan gadget lebih dari 2 jam secara terusmenerus yaitu sebanyak 23 orang. Pada sering menggunakan gadget dalam posisi tidur, kelainan refraksi paling banyak ditemukan pada responden yang sering menggunakan gadget dalam posisi tidur yaitu sebanyak 27 orang.

Tabel 3.5. Tabel Hubungan Aktivitas Diluar Ruangan Responden dengan Terjadinya Kelainan Refraksi pada Siswa SMP Swasta Bersama Berastagi Tahun 2019.

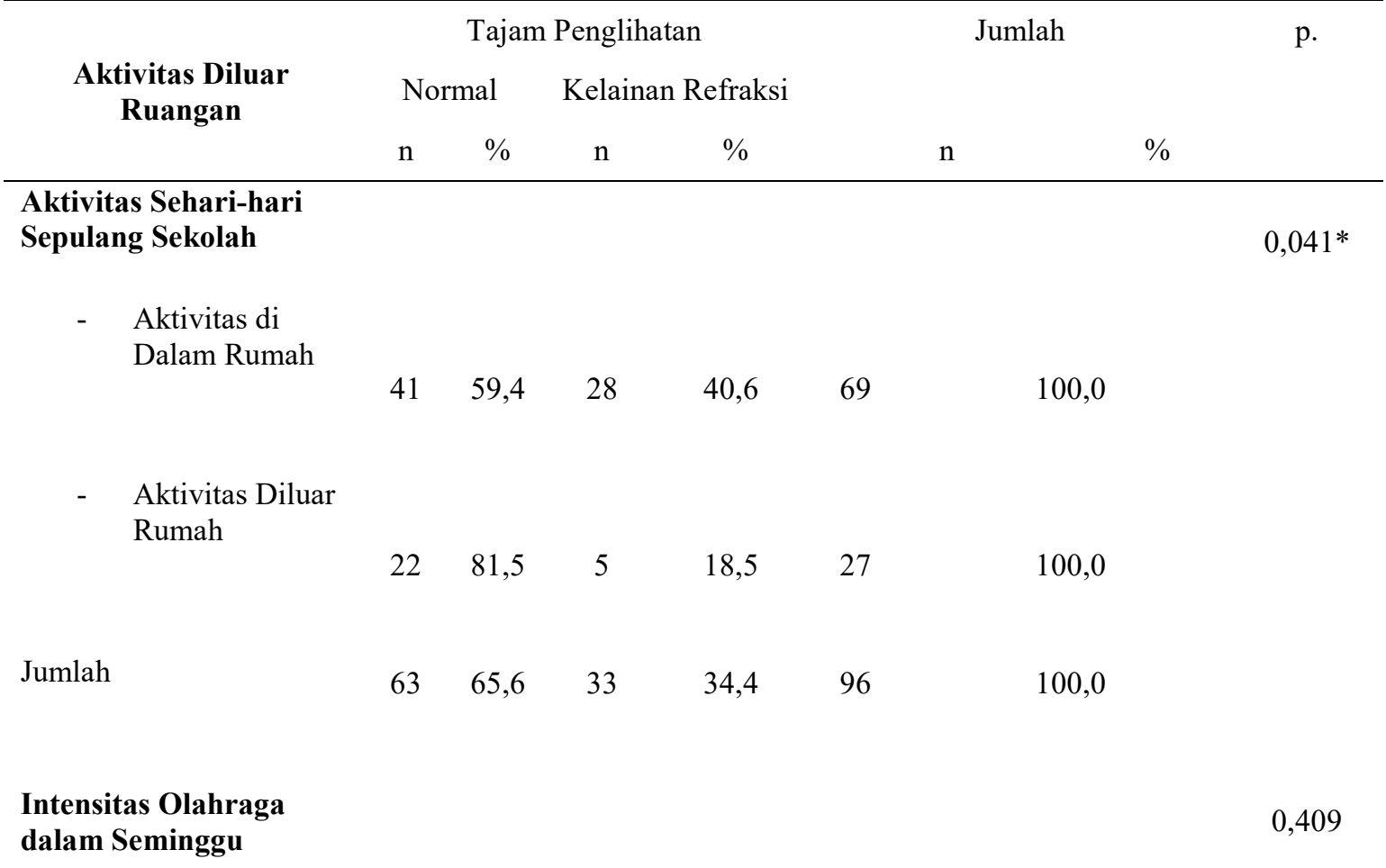


Rodiah Rahmawaty Lubis et.al The Relationship Between

\begin{tabular}{lllllll}
\hline$-\quad \begin{array}{l}0-5 \text { jam } \\
\text { Seminggu }\end{array}$ & 49 & 63,6 & 28 & 36,4 & 77 & 100,0 \\
$-\quad \begin{array}{l}\text { 6-9 jam } \\
\text { Seminggu }\end{array}$ & 14 & 73,7 & 5 & 26,3 & 19 & 100,0 \\
Jumlah & 63 & 65,6 & 33 & 34,4 & 96 & 100,0 \\
\hline
\end{tabular}

Dari tabel 3.5, didapatkan kelainan refraksi paling banyak terjadi pada responden yang melakukan aktivitas sehari-hari di dalam rumah yaitu sebanyak 28 orang. Sementara pada intensitas olahraga dalam seminggu, kelainan refraksi paling banyak terjadi pada responden yang melakukan olahraga 0-5 jam dalam seminggu yaitu sebanyak 28 orang.

Dari tabel 3.1 dapat dilihat bahwa frekuensi responden terbanyak adalah berjenis kelamin laki-laki yaitu sebanyak 50 orang dan responden berjenis kelamin perempuan sebanyak 46 orang. Pada tabel tersebut juga dapat dilihat bahwa kelainan refraksi lebih banyak dialami oleh responden berjenis kelamin perempuan yaitu sebanyak 21 orang $(45,7 \%)$ dari jumlah seluruh responden penelitian, sedangkan yang berjenis kelamin laki-laki sebanyak 12 orang $(24,0 \%)$ dari jumlah seluruh responden penelitian. Hasil Penelitian ini memiliki kesamaan dengan penelitian yang di lakukan oleh Enira (2016) dimana kelainan refraksi lebih sering terjadi pada perempuan $(45,5 \%)$ dibandingkan dengan laki-laki (40,4\%). Dengan menggunakan uji Chi Square didapatkan nilai p sebesar 0,026 $(<0,05)$ yang menunjukkan adanya hubungan antara jenis kelamin dengan terjadinya kelainan refraksi. Hasil penelitian ini memiliki kesamaan dengan penelitian yang dilakukan oleh Arsa (2018) dimana dengan menggunakan uji Chi Square didapatkan nilai p sebesar $0,026(<0,05)$.

Dari hasil penelitian dapat dilihat bahwa frekuensi suku responden dengan penderita kelainan refraksi terbanyak terdapat pada suku Karo dengan jumlah sebanyak 19 orang (31,7\%) dibandingkan dengan suku-suku lainnya. Dengan menggunakan uji Chi Square didapatkan nilai $\mathrm{p}$ sebesar 0,441 $(>0,05)$ yang menunjukkan tidak adanya hubungan suku responden dengan terjadinya kelainan refraksi. Hasil penelitian ini memiliki kesamaan dengan penelitian yang dilakukan oleh Lestari (2019) dimana dengan menggunakan uji Chi Square didapatkan hasil nilai p sebesar $0,157(>0,05)$. Hal ini kemungkinan terjadi karena penelitian tersebut dilakukan pada populasi yang didominasi oleh suku Bali, dimana hanya terdapat $13,4 \%$ responden yang merupakan suku non-bali. Sama halnya dengan penelitian ini yang dilakukan pada populasi yang didominasi oleh suku Karo sebanyak 60 orang (62,5\%) dari total keseluruhan responden penelitian.

Dari tabel 3.1 dapat dilihat bahwa frekuensi pekerjaan orangtua responden terbanyak adalah petani dengan jumlah sebanyak 55 orang dari total keseluruhan responden penelitian. Namun frekuensi kelainan refraksi terbanyak terdapat pada responden dengan orangtua yang memiliki pekerjaan sebagai wiraswasta yaitu sebanyak 18 orang $(52,9 \%)$. Dengan menggunakan uji $C h i$ Square didapatkan hasil nilai p sebesar $0,021(<0,05)$ yang menunjukkan adanya hubungan antara faktor pekerjaan orangtua responden dengan terjadinya kelainan refraksi. Hasil penelitian ini berbeda dari hasil penelitian yang dilakukan oleh Arsa (2018) dimana dengan menggunakan uji Chi Square didapatkan hasil nilai p sebesar $0,117(>0,05)$ yang menunjukkan tidak adanya hubungan antara faktor pekerjaan orangtua responden dengan terjadinya kelainan refraksi.

Dari tabel 3.2 dapat dilihat bahwa dari penelitian ini didapatkan hasil dimana dari 12 orang responden dengan riwayat kelainan refraksi pada saudara kandung, terdapat sebanyak 6 orang $(50,0 \%)$ yang mengalami kelainan refraksi. Dengan menggunakan uji Chi Square didapatkan nilai p sebesar 0,223 $(>0,05)$ yang menunjukkan tidak adanya hubungan antara riwayat kelainan refraksi pada saudara kandung dengan terjadinya kelainan refraksi. Hasil penelitian ini sama dengan hasil penelitian yang dilakukan oleh Arsa (2018) dimana didapatkan nilai p sebesar 0,986 
$(>0,05)$ yang didapatkan dengan uji Chi Square yang berarti tidak terdapat hubungan antara faktor riwayat kelainan refraksi pada saudara kandung dengan terjadinya kelainan refraksi.

Dari tabel 3.3 dapat dilihat bahwa dari penelitian ini, dari hasil uji statistik Chi Square terdapat hubungan antara jarak pada saat membaca buku dengan terjadinya kelainan refraksi dengan nilai $\mathrm{p}$ sebesar $0,001(<0,05)$ yang menyatakan adanya hubungan antara jarak pada saat membaca buku dengan terjadinya kelainan refraksi. Hasil penelitian ini berbeda dengan penelitian yang dilakukan oleh Wulansari (2018) dimana dari hasil uji statistik Chi Square didapatkan nilai p sebesar $0,364(>0,05)$ yang menggambarkan tidak adanya hubungan antara jarak pada saat membaca dengan terjadinya kelainan refraksi.

Pada hasil penelitian dari hubungan antara faktor membaca dengan duduk yang tegak dengan terjadinya kelainan refraksi, didapatkan nilai p sebesar $0,000(<0,05)$ dari hasil uji statistik Chi Square yang berarti adanya hubungan antara faktor posisi duduk saat membaca dengan terjadinya kelainan refraksi. Hasil penelitian ini sama dengan hasil penelitian yang dilakukan oleh Kistianti,dkk. (2008) dimana dengan menggunakan uji Chi Square, didapatkan nilai p sebesar 0,05 $(<0,05)$ yang berarti terdapat hubungan yang signifikan antara faktor membaca dengan posisi duduk yang tegak dengan terjadinya kelainan refraksi.

Untuk hubungan antara faktor menggunakan lampu belajar pada saat membaca, dari hasil uji statistik Chi Square didapatkan nilai p sebesar 0,117 $(>0,05)$ yang menyatakan tidak adanya hubungan antara faktor menggunakan lampu belajar pada saat membaca dengan terjadinya kelainan refraksi. Hasil penelitian ini sama dengan penelitian yang dilakukan oleh Wulansari (2018) dimana dari hasil uji statistik Chi Square didapatkan nilai p sebesar 0,612 $(>0,05)$ dimana tidak terdapat hubungan yang berarti antara faktor menggunakan lampu belajar pada saat membaca dengan terjadinya kelainan refraksi.

Menurut teori, terjadinya kelainan refraksi disebabkan oleh lamanya aktivitas melihat jarak dekat akan menyebabkan terbentuknya bayangan buram di retina yang akan memulai proses kimia pada retina untuk menstimulasi perubahan biokimia dan struktural pada sklera dan koroid yang menyebabkan elongasi aksial (Ramamurthy, et al., 2015). Teori lainnya menyatakan terjadinya kelainan refraksi disebabkan oleh jarak melihat yang semakin dekat sehingga menyebabkan semakin kuatnya akomodasi mata. Akomodasi yang terjadi secara terus menerus menyebabkan tonus otot siliaris menjadi tinggi dan lensa menjadi cembung (Kistianti, 2008).

Dari tabel 3.4 dapat dilihat hasil penelitian dari hubungan antara faktor lama penggunaan gadget dalam sekali pemakaian terhadap terjadinya kelainan refraksi, didapatkan nilai $\mathrm{p}$ sebesar $0,000(<0,05)$ dari hasil uji statistik Chi Square yang berarti terdapat hubungan antara lama penggunaan gadget dalam sekali pemakaian terhadap terjadinya kelainan refraksi. Hasil penelitian ini sama dengan hasil dari penelitian yang dilakukan oleh Sofiani (2016) dimana dari hasil uji Chi Square didapatkan nilai p sebesar $0,049(<0,05)$ yang menunjukkan adanya hubungan yang signifikan. Hasil penelitian ini sesuai dengan teori yang menyatakan bahwasanya pada seseorang yang menggunakan gadget dengan intesitas yang tinggi dapat terjadi computer vision syndrome (CVS) yang memiliki gejala penurunan penglihatan atau kelainan refraksi (Siregar, 2013).

Berdasarkan dari hasil uji statistik Chi Square pada faktor sering menggunakan gadget dalam posisi tidur, didapatkan nilai $\mathrm{p}$ sebesar $0,023(<0,05)$ yang berarti terdapat hubungan antara menggunakan gadget dalam posisi tidur dengan terjadinya kelainan refraksi. Hasil penelitian ini berbeda dengan hasil penelitian yang dilakukan oleh Arsa (2018) dimana dari hasil uji Chi Square didapatkan nilai $p$ sebesar $0,079(>0,05)$ yang berarti tidak terdapat hubungan yang signifikan.

Dari tabel 3.5 dapat dilihat hasil penelitian dari hubungan antara faktor aktivitas sehari-hari sepulang sekolah didapatkan hasil uji statistik Chi Square dengan nilai p sebesar 0,041 $(<0,05)$ yang berarti terdapat hubungan yang signifikan antara faktor aktivitas sehari-hari dengan terjadinya kelainan refraksi. Hasil penelitian ini sama dengan hasil penelitian yang dilakukan oleh Septiany (2015) dimana dengan menggunakan uji Chi Square didapatkan nilai p sebesar 0,000 (< $0,05)$ yang berarti terdapat hubungan yang signifikan.

Terdapat beberapa teori yang menyatakan bagaimana aktivitas diluar ruangan dapat mencegah terjadinya kelainan refraksi. Satu teori menyatakan paparan cahaya yang terang akan 
menstimulasi pelepasan dopamin yang dapat menghambat elongasi bola mata (French, et al., 2013). Teori lain menyatakan paparan radiasi ultraviolet B (UVB) dapat menstimulasi pelepasan vitamin $\mathrm{D}$ yang berperan dalam pembentukan kolagen yang merupakan komponen utama sklera (Ramamurthy, et al., 2015).

Berdasarkan dari hasil uji statistik Chi Square pada faktor intensitas olahraga dalam seminggu terhadap terjadinya kelainan refraksi, didapatkan nilai $\mathrm{p}$ sebesar $0,409(>0,05)$ yang berarti tidak terdapat hubungan antara faktor intensitas olahraga dalam semingu dengan terjadinya kelainan refraksi. Hasil penelitian ini tidak sama dengan hasil penelitian yang dilakukan oleh Sofiani (2016) dimana dari hasil penelitian yang dilakukan, didapatkan hasil uji Chi Square dengan nilai $\mathrm{p}$ sebesar $0,017(<0,05)$ yang berarti terdapat hubungan yang signifikan antara faktor intensitas olahraga dalam seminggu terhadap terjadinya kelainan refraksi.

\section{KESIMPULAN}

Dari hasil penelitian ini dapat disimpulkan bahwa berdasarkan karakteristik kelainan refraksi pada siswa SMP Swasta Bersama Berastagi, penderita kelainan refraksi paling banyak ditemukan pada responden wanita yaitu sebanyak $24,9 \%$, pada usia paling banyak adalah 12 dan 13 tahun sebanyak masing-masing $11,5 \%$, pada suku paling banyak adalah suku Karolsebanyak 18,2\%, pada kelas yang paling banyak adalah kelas 2 sebanyak $13,4 \%$, dan pada pekerjaan orang tua paling banyak adalah pada responden yang orangtua nya bekerja sebagai wiraswasta yaitu sebanyak $17,2 \%$.

Untuk hasil perhitungan statistik dengan uji korelasi Chi Square memperlihatkan tidak terdapat hubungan bermakna antara terjadinya kelainan refraksi dengan faktor riwayat kelainan refraksi pada saudara kandung $(\mathrm{p}=0,223)$, dan terdapat hubungan bermakna antara aktivitas membaca $(\mathrm{p}=0,001)$, aktivitas menggunakan gadget $(\mathrm{p}=0,0001)$ dan akivitas diluar ruangan $(\mathrm{p}=$ $0,041)$

\section{UCAPAN TERIMAKASIH}

Artikel ini merupakan salah satu hasil dari Program Pengabdian kepada Masyarakat yang Dibiayai oleh dana NON PNBP Universitas Sumatera Utara Sesuai dengan Surat Perjanjian Penugasan Pelaksanaan Pengabdian kepada Masyarakat Program Mono Tahun Dosen Muda Tahun Anggaran 2019. Oleh karena itu, diucapkan terima kasih kepada Rektor Universitas Sumatera Utara atas dukungan dana dan fasilitas yang diberikan. Terima kasih juga kepada Mitra pada kegiatan pengabdian ini.

\section{DAFTAR PUSTAKA}

Adile A. V., Tongku, Y. \& Rares, L. M. (2016), 'Kelainan refraksi pada pelajar SMA Negeri 7 Manado', Journal e-Clinic (eCl), vol. 4, no. 1.

Arsa, D. M. (2018), 'Faktor Faktor Terjadinya Kelainan Refraksi pada Pelajar Kelas 3 SMP AlAzhar di Kota Medan Tahun 2018', [Thesis] Fakultas Kedokteran Universitas Sumatera Utara, Medan.

Denniston, A. K. O. \& Murray, P. I. 2018. Oxford Handbook of Ophthalmology, 4th edn, Oxford University Press, New York. 
Enira, T. A., (2016), 'Prevalensi dan Penyebab Kelainan Refraksi pada Anak Usia Sekolah di Sekolah Dasar Muhammadiah 16 Palembang, [Skripsi] Fakultas Kedokteran Universitas Muhammadiah Palembang, Palembang.

French, A. N., Ashaby, R. S., Morgan I. G., Rose, K. A., (2013). 'Time outdoors and the prevention of myopia’, Experimental Eye Research, vol. 114, pp. 58-68.

Kistiani, F., (2008), 'Faktor risiko yang berhubungan dengan terjadinya cacat mata miopia pada mahasiswa', Jurnal UGM, vol. 3, pp.78-84

Kumar, N., Jangra, B., Jangra, N. S. \& Pawar, N. (2018), 'Risk factors associated with refractive error among medical students', International Journal of Community Medicine and Public Health, vol. 5, no. 2, pp. 634-638.

Lestari, K. D., Handayani, T. A., Pemayun, C. I. D., Manuaba I. B. P., (2019), 'Karakteristik dan perbedaan kelainan refraksi pada anak usia sekolah dasar di Sekolah Dasar Cipta Darma Denpasar Februari 2014', Medicina 50(2): 220-225. DOI:10.15562/Medicina.v50i2.224.

Ramamurthy, D., Lin Chua, S. Y., Saw, S. M., (2015), 'A review of environmental risk factors for myopia during early life, childhood and adolescence', Clinical and Experimental Optometry, vol. 98(6), pp. 497-506.

Septiany, T., Setyandriana, Y., (2015), 'Pengaruh aktivitas luar ruangan terhadap prevalensi miopia di desa dan di kota usia 9-12 tahun', Universitas Muhammadiah Yogyakarta.

Siregar, N. H., (2013), 'Computer Vision Syndrome, [Makalah] Fakultas Kedokteran Universitas Sumatera Utara.

Sofiani, A., Puspita Santik, Y., (2016), 'Faktor-faktor yang mempengaruhi derajat miopia pada remaja (studi di SMA Negeri 2 Temanggung Kabupaten Temanggung)', Unnes Journal of Public Health, vol. 5(2), pp.176-185

Syafi'in, Wibowo, A., (2013), 'Pengaruh Pemberian Kacamata Koreksi pada Penderita Myopia terhadap Prestasi Belajar Siswa Kelas VII SMP Negeri 34 Surabaya'. Jurnal Biometrika dan Kependudukan, vol. 2, no. 1, pp. 82-87.

Wulansari, D., Rahmi, F. L. \& Nugroho, T. (2018), 'Faktor-Faktor yang Berhubungan dengan Miopia pada Anak SD di Daerah Perkotaan dan Daerah Pinggiran Kota', Jurnal Kedokteran Diponegoro, vol. 7, no. 2. 